\title{
Development and Implementation of Alternative Concept for Expected and Unexpected Losses in Corporations
}

\author{
Viktoriya Manuylenko ${ }^{1,5}$, Denis Ryzin ${ }^{1}$, Mariia Koniagina ${ }^{2}$, \\ Nina Lipchiu ${ }^{3}$, Liubov Setchenkova ${ }^{4}$ \\ ${ }^{1}$ Institute of Economics and Management, Department for Finance and Credit, North Caucasus Federal \\ ${ }^{2}$ The Department of Economics and Finance Department of Economics, The North-West Institute of \\ management, of the Russian Presidential Academy of National Economy and Public Administration, St. \\ Dnepropetrovskaya str., 8, Petersburg, 199178, Russia \\ ${ }^{3}$ Faculty for Finance and Credit, Finance Department,Kuban State Agrarian University, 13 Kalinin Street, \\ Krasnodar, 350044, Russia \\ ${ }^{4}$ Corporate Finance and Corporate Management Department, Financial University under the \\ Government of the Russian Federation, 49 Leningradsky Prospect, Moscow, 125993, Russia \\ ${ }^{5}$ Faculty for Regional Development, Department for Regional Economics, Russian Technological University, \\ Stavropol Branch, 8 Kulakov Prospect, Stavropol, 355035, Russia
}

\begin{abstract}
The study suggests alternative conception of expected and unexpected losses in corporations. Unlike the classical conception, it suggests backing up expected losses with risk capital, taking into account loss causes during different phases of business cycle. Whereas unexpected losses that are the source of uncertainty should be adjusted based on adapted VaR method tests, stress tests and limitations that include principles of dynamic back up allocations. That should ensure timely forecast of significant financial risks guaranteeing efficient development of risk profile of corporations, and in the end increasing potential for efficient control on financial risks.

From the standpoint of further conception advancing, a method for determining unexpected VaR losses was developed and implemented; it is supported
\end{abstract}

DOI: $10.18421 /$ TEM93-37

https://doi.org/10.18421/TEM93-37

Corresponding author: Viktoriya Manuylenko,

Institute of Economics and Management, Department for Finance and Credit, North Caucasus Federal University, Stavropol, Russia

Email: vika-mv@mail.ru

Received: 25 March 2020.

Revised: 30 July 2020.

Accepted: 07 August 2020.

Published: 28 August 2020.

(cc) BY-NC-ND (C) 2020 Viktoriya Manuylenko et al; published by UIKTEN. This work is licensed under the Creative Commons Attribution-NonCommercial-NoDerivs 4.0 License.

The article is published with Open Access at www.temjournal.com with special software dedicated to bankruptcy risk symptoms identification in corporations.

Keywords - Expected and unexpected losses, alternative concept, financial risk, risk management

\section{Introduction}

Corporations' business activities are associated with a number of financial risks. Theory and practice demonstrate terminological contradictions when defining content of losses incurred during exposure to financial risks.

The purpose of the study is to adapt and implement a method for determining unexpected VaR losses within the framework of alternative conception for expected and unexpected losses; that is supported with application of special software focused at bankruptcy risk exposure for corporations. The achievement of the purpose was linked to the following tasks solution: develop and implement alternative conception for expected and unexpected losses in corporations; adapt and implement the method for determining unexpected VaR losses applying special software focused at identification of bankruptcy risk exposure for corporations. Theoretical and methodological ground of the study incorporates works of foreign and Russian scientists and specialists, as well as internal regulatory framework of corporations.

Methodological basis of the study includes logical, situational, and process-based scientific approaches applied to research process of financial risks assessment in corporations. Scientific and special methods listed below were applied to design and 
implement toolkit for determination of unexpected VaR losses, supported with special software focused at identification of bankruptcy risk exposure for corporations. Out of general scientific and special methods, the following were attracted: inductive, deductive, analysis, synthesis, observation, grouping, analogy, system thinking, abstract-logical, analytical, graphical, comparative, economic and statistical, economic-mathematical, extrapolation, coefficient analysis, MS EXCEL and special EXCEL-VBA software.

The working hypothesis of the research is based on the need to develop and implement an alternative conception for expected and unexpected losses as well as to adapt and implement the method for determining $\mathrm{VaR}$ unexpected losses. Theoretical significance of the study lies in development of provisions for financial risks assessment in corporations. Practical significance of the study lies in development and implementation of specific approaches, methods, techniques, tools, models and practical recommendations that should form theoretical, methodological and practical basis for development of tools for estimation of unexpected losses.

\section{Method}

\subsection{Transition from Classical to Alternative Concept of Expected and Unexpected Financial Losses in Corporations}

Smith [14] directly links small profits with high / low risk. He suggested inclusion of "risk charge" element into assessment of business profit, which represents compensation for possible loss caused by business activities.

According to Fabozzi [6], the financial risk represents a flow of payments by stakeholders $\backslash$ emitters that does not meet deadlines for financial obligations.

Brigham and Gapensky [2], unlike Fabozzi, consider financial risk as secondary for stakeholders /common shares holders, since it reflects decision to invest borrowed funds / preferred shares.

Skovorodkina [13] recognizes that companies are exposed to financial risk in many business operations, and considers financial risk as probable negative financial result in the form of income shortfall when organization performs in conditions of instability.

From the standpoint of methodological tools development for assessing corporation's expected and unexpected losses at financial risk exposure, the following interpretations are of special interest.

Domashchenko and Finogenova [4] associate financial risk with possible occurrence of unexpected financial losses (i.e. decrease in profits, loss of capital or monetary assets, etc.), defining it as financial activity that reflects uncertainty of the outcome and possible financial losses in case of its unfavourable implementation.

Ploshkin [10] views the term of "financial risk" of a corporation through the probabilistic character of an event, which in the long run may bring company to losses.

Unfortunately, Domashchenko, Finogenova, Ploshkin defining financial risk ignore some inaccuracies when they divide losses into expected and unexpected.

In our opinion, improvement of substantial financial risks control in corporations requires change of the method for determining expected and unexpected losses. The change of philosophy and problem interpretation as well as development of new approaches to the problem solution and development of methodological and operational environment provide for correct implementation of alternative concept.

In the classic version, risks are regulated gradually:

1) determination of market premiums in service costs; 2) creation of funds and reserves; 3) own capital. Sources for the loss cover are divided into current (current income and formed reserves) and capital (own capital). Any kind of operational activity in corporations causes changes after the activity:

\section{CHANGES $=$ EXPECTED ELEMENT + UNEXPECTED ELEMENT (1)}

The classical approach to financial risks control suggests that reserves and current income compensate for expected losses, whereas own capital compensates for unexpected losses. All expected losses are covered within financial margin, i.e. market price benefit (risk transfer) or company's reserves (early risk acceptance). Ideally, expected loss volumes and reserve volumes should converge, when the latter are created, expected loss amounts are corrected by the sum of increase in value, or double insurance of the same financial risk is applied. Unexpected losses that exceed the level of estimated market value of the service and created reserves are determined in perspective after update of future losses. Simultaneously, it is more likely to recon that future loss volume is close to the anticipated, which allows its prior allocation. The classical method of financial risks control implies that both own capital and included reserve funds in a close connection protect corporations from expected and unexpected losses and form the $1^{\text {st }}$ and the $2^{\text {nd }}$ security levels. Thus, it appears that capital is created for loss and damage compensations, but not for ensuring successful performance of corporations. 
Sinkey [12] stipulates that "not a single smart lender will identify reserve funds to compensate bad debts from a potential borrower as an element of the company's capital". German economists Beger, Kruschwitz, Podochnik and Rast [1] distinguish specific function of capital of industrial companies as buffer for periods of probable losses.

In Russian practice, application of terms "fund" and "capital" is not specific. On the one hand, funds became popular. Latin term for fund ("fundus") means "basis". It contains resources for targeted use, which predetermines creation of various special purpose funds. On the other hand, in financial statements they apply the term "reserve capital", whereas in Latin "capital" means the main property for multiple purposes.

The research was selectively arranged in corporations that reflect general trend prevailing in most commercial corporations in the region.

"Arnest" JSC - processing industries / production of perfumes and cosmetics ("Arnest" Official Site);

"Soyuzpechat" JSC - wholesale and retail sales / retail trade in non-stationary facilities and markets (Official site of the Territorial body of the Federal State Statistics Service in the North Caucasus Federal District);

"Baysad" JSC - agriculture, forestry, hunting, fishing and fish farming / poultry breeding ("Baysad" JSC Official Site);

"Georgievsky Fittings Plant" LLC - processing production / production of faucets and valves (Official site of "Georgievsky Fittings Plant").

Table 1. Evaluation of researched JSCs' compliance with national legislator requirements on creation of reserve funds

\begin{tabular}{|c|c|c|c|}
\hline \multirow{2}{*}{ YY } & \multicolumn{3}{|c|}{ "Arnest" JSC } \\
\cline { 2 - 4 } & $\begin{array}{c}\text { Thousan } \\
\text { d Rubles }\end{array}$ & $\begin{array}{c}\text { \% to nominal } \\
\text { capital }\end{array}$ & $\begin{array}{c}\text { \% to own } \\
\text { capital }\end{array}$ \\
\hline 2011 & 1620 & 5,0 & 0,07 \\
\hline 2012 & 1620 & 5,0 & 0,07 \\
\hline 2013 & 1620 & 5,0 & 0,06 \\
\hline 2014 & 1620 & 5,0 & 0,05 \\
\hline 2015 & 1620 & 5,0 & 0,04 \\
\hline 2016 & 1620 & 5,0 & 0,04 \\
\hline 2017 & 1620 & 5,0 & 0,03 \\
\hline \multicolumn{3}{|c|}{} & "Soyuzpechat" JSC \\
\hline 2011 & 108 & 514,3 & 0,07 \\
\hline 2012 & 1 & 4,8 & 0,001 \\
\hline 2013 & 1 & 4,8 & 0,001 \\
\hline 2014 & 1 & 4,8 & 0,001 \\
\hline 2015 & 1 & 4,8 & 0,001 \\
\hline 2016 & 1 & 4,8 & 0,0005 \\
\hline 2017 & 1 & 4,8 & 0,0005 \\
\hline
\end{tabular}

Source: calculations provided by the authors V. V. Manuilenko, D. A. Ryzin on the data [3].
The main purpose of reserve fund in organizations where its availability is mandatory is compensation for unexpected losses that arise in the course of operational activities, which in practice reduces loss reflected in financial statements. It means that joint stock companies (JSCs) and production cooperatives deliberate financial risk protection in reserve funds Table 1.

According to the dynamics of reserve funds absolute value, as well as its share in nominal and total capital, the formal nature of its creation can be noted. That indicates low financial risk culture in the researched joint-stock companies. "Arnest" JSC practicing better corporate governance than that in "Soyuzpechat" JSC, considers upper limit for reserve fund corresponding to nominal capital, but in Russia, it is much lower than the values accepted in international practice $(10 \%-40 \%)$. "Baysad" JSC does not form any reserve fund. In critical situation, such reserve funds cannot compensate for real unexpected losses of corporations as established by the Russian legislator. The Russian legislator, on the one hand, specifying the purpose of reserve funds i.e. unexpected loss covering, stipulates that emergent situation is approximation of uncertainty. Thus, theoretically it excludes possibility of certain events, which is unacceptable in case of uncertainty. In conditions when economic processes are focused on the future, the issue of uncertainty is inevitable. On the other hand, the term "reserve capital" in financial statements carries multi-purpose nature, so the Russian legislator admits obvious contradiction when intends its normative purpose. By its economic nature, reserve capital compensates for expected losses of organizations. At the same time, hierarchy, methods subordination, techniques, and instruments for regulation of financial risks are disrupted, ultimately having negative effect at the financial success of the corporations.

Therefore, uncertainty arises at the point of determining the amount of losses that should be covered by capital, which justifies the concept of "risk-capital" in corporations.

Risk capital should reflect aggregated capital demand inside corporations, that is characterized by the value of accepted risk (volatility of net income, that is a source of contributions to the funds), and shows risk proneness of stakeholder / owners, financial managers, etc. Developed corporate financial risk culture ensures that financial decisions of management include expected changes and the source of risk equals to unexpected changes only. Each corporation, assessing arising negative events should take financial culture into account when pricing and minimizing in the end the financial risks attributable to capital. By proper recognition of expected losses and their consideration in pricing and 
reserve policies of organizations, the risk-capital is reduced. The other way round is also possible; that shows the dynamic character of its nature. Financial managers should regularly monitor projected amounts of risk capital.

So, it is fair to refer to risk capital of corporations [8] as to reserved finances implied to cover financial risk and created to compensate for expected losses (i.e. loss of financial stability, liquidity, business activity, loss of business activities efficiency, irrational financial structure of capital, etc.), which the management may put at risk, and lose it in the designated period in order to save business. In relative terms, risk-capital is the share of a corporation's capital that is exposed to risk by financial management and is established with a certain probability for a certain period. Unlike classical conception, alternative or improved conception stipulates that risk capital protects organizations from expected losses. This position is justified with the concept that reasonable financial risk-decisions of managers must identify expected losses true to life, whereas unexpected losses become a case of financial risk. After the expected losses are calculated, unexpected losses are noted as uncertainty, if difference between future losses and their expected value is zero / negative, the determination of unexpected losses is meaningless. Unexpected losses are controlled with methodological tools of organization's financial risk management system - stress testing, limits, etc. One of the key differences between risk capital and capital that is not referred to risk is that the first records causes of possible losses, whereas the second states only the facts of loss - that was confirmed by practical research.

Regulation of risk capital in financial management system of corporations is aimed at their risk exposure control, as well as combining expected losses with established degree of importance for certain types of financial risks. Ultimately, they are safe on planning significant risks, efficient allocation of funds by structural units, candid assessment of efficiency of risk control activities. That is, riskcapital integrates significant risks that can characterize certain conditions of organizations' development and positively influence risk-profile balancing in organizations. The size of risk-capital in corporations demonstrates the outcome of financial risks control, which is the volume of financial backup. It should be noted that in large corporations control over key financial risks can be allocated in a separate block of activities.

Implementation of improved conception for expected and unexpected losses should:

- provide determination of expected losses defining their causes;
- if unexpected losses occur contribute to development of effective control methods, considering specifics of organizational and legal form of management, type of business, composition of the financial regulatory body, etc ;

- increase potentials of financial risk control methods;

- integrate methods, techniques, and control and evaluation tools.

Since financial risk of corporations represents joint risk with individual groups of stakeholders implementation of improved conception for planning expected losses demands obtaining reliable information about stakeholders.

\subsection{Implementation of Alternative Conception for Expected and Unexpected Losses in Corporations. Method for Determining Unexpected VaR Losses Applying Special Software}

Considering that in conditions of uncertainty, unexpected losses represent source of financial risks occurrence, stakeholder behaviour after potential losses can be measured by means of statistical model, which integrates cost-wise, probabilistic and temporary measurement of financial risks. VaR can represent such model that directly estimates unexpected losses, their most probable distribution and frequency over a specified period.

Expected financial loss costs $=$ Actual costs $\times$ Bankruptcy probability

Expected financial loss costs represent losses due to financial difficulties arising from attracted resources. That means there is potential possibility of additional tax protection benefits loss; bearing direct costs of bankruptcy procedure (i.e. costs of lost opportunities: time spent on trial with stakeholders/creditors, temporary disregard of business management, legal costs, etc.); hidden costs, agency fees - excessive debt, excessive risks, insufficient cash flows to meet obligations on interest payments, etc.

Financial difficulties may change motivation of top management and distance individual stakeholders suppliers and customers, causing a decrease in operating profit margins, etc. In such situation, stakeholders - suppliers behaviour is described with their demand of cash payments, worsening the already difficult financial situation of organization and do not seek to invest in cooperation, customers may prefer a competitor if their priority is long-term relationships and long-term organization vitality. According to separate estimates, the repulsion of stakeholders - customers, suppliers, employees, "debt 
veil" and shifting of risks can cost up to $20 \%$ of corporation's value. At a certain point, growth of borrowing most likely provokes rapid growth of financial difficulties and they turn to unexpected losses.

Unexpected losses are determined with support of special Excel - VBA software in the VBA programming language "Software for determining expected and unexpected losses in commercial corporate non-credit organizations" [8], Table 2., Figure 1. - 4.

Table 2. Unexpected losses determination in corporations based on Monte Carlo modelling, in thousand rubles

\begin{tabular}{|c|c|c|c|c|}
\hline \multirow{2}{*}{ Indicators } & \multicolumn{2}{|c|}{ "Arnest" JSC } & \multicolumn{2}{|c|}{ "Baysad" JSC } \\
\hline & 2017 & 2019 & 2017 & 2017 \\
\hline 1. Expected losses & $\begin{array}{c}\infty \\
\overbrace{\infty} \\
\tilde{N}\end{array}$ & $\begin{array}{l}\mathscr{\infty} \\
\infty \\
\infty \\
\infty \\
\infty\end{array}$ & 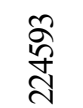 & $\frac{m}{\text { m}}$ \\
\hline $\begin{array}{l}\text { 2. Maximum } \\
\text { possible losses at } \\
\text { the established } \\
\text { parameters and } \\
\text { assumptions on the } \\
\text { basis of the model } \\
\text { VaR }_{90}\end{array}$ & $\frac{\sqrt{2}}{\frac{2}{6}}$ & $\frac{\text { }}{\frac{8}{8}}$ & $\frac{\bar{\sigma}}{\delta}$ & 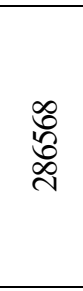 \\
\hline \multirow[t]{2}{*}{$\begin{array}{l}\text { 3. Unexpected } \\
\text { losses } \mathrm{VaR}_{90} \\
\text { (line } 2-\text { line } 1 \text { ) }\end{array}$} & $\begin{array}{l}\frac{\mathbb{N}}{\infty} \\
\infty \\
\stackrel{+}{N}\end{array}$ & $\begin{array}{l}\bar{T} \\
\infty \\
\infty \\
i n\end{array}$ & $\begin{array}{l}\infty \\
2 \\
0 \\
0 \\
6\end{array}$ & 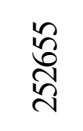 \\
\hline & \multicolumn{2}{|c|}{$\begin{array}{c}\text { "Soyuzpechat" } \\
\text { JSC }\end{array}$} & \multicolumn{2}{|c|}{$\begin{array}{c}\text { "Georgievsky } \\
\text { Fittings Plant" } \\
\text { LCC }\end{array}$} \\
\hline 1. Expected losses & 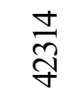 & $\underset{\text { ते }}{\stackrel{\sigma}{\pi}}$ & $\frac{m}{\text { ले }}$ & $\frac{\nexists}{\stackrel{У}{~}}$ \\
\hline $\begin{array}{l}\text { 2. Maximum } \\
\text { possible losses at } \\
\text { the established } \\
\text { parameters and } \\
\text { assumptions on the } \\
\text { basis of the model } \\
\text { VaR }_{90}\end{array}$ & $\begin{array}{l}\text { §̊ } \\
\varnothing \\
\infty \\
\infty \\
n\end{array}$ & 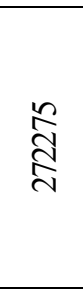 & 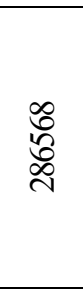 & 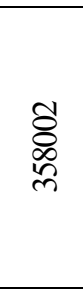 \\
\hline $\begin{array}{l}\text { 3. Unexpected } \\
\text { losses } \mathrm{VaR}_{90} \\
\text { (line } 2-\text { line } 1 \text { ) }\end{array}$ & $\begin{array}{l}\infty \\
\infty \\
\infty \\
\frac{\infty}{n}\end{array}$ & 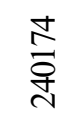 & 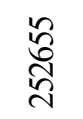 & $\begin{array}{l}\infty \\
\infty \\
\infty \\
\frac{n}{m}\end{array}$ \\
\hline
\end{tabular}

Source: calculations provided by the authors V. V. Manuilenko, D. A. Ryzin on the data [3].

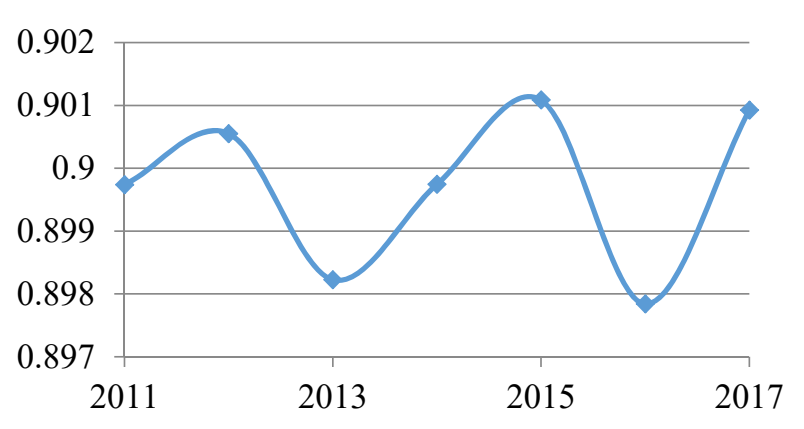

Figure 1. Distribution of the maximum possible actual losses on the basis of Monte-Carlo simulation in "Baysad" JSC, thousand rubles

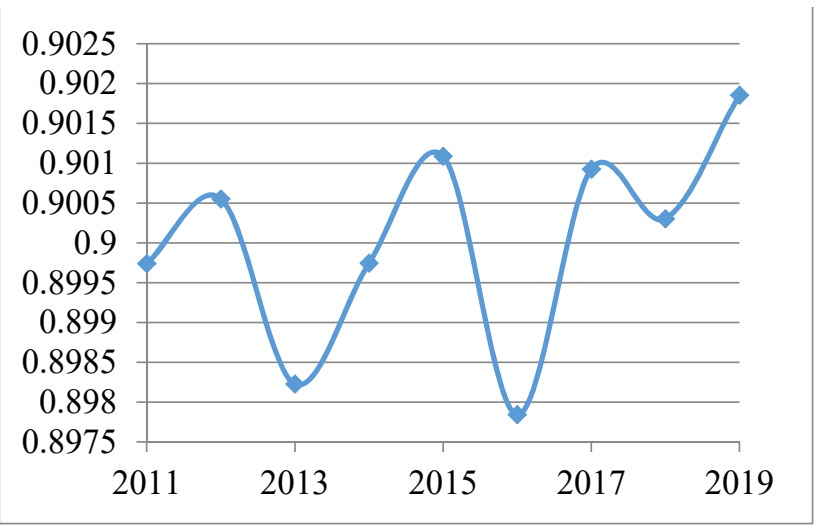

Figure 2. Distribution of predicted maximum possible losses based on Monte-Carlo simulation at” Baysad” JSC, thousand rubles

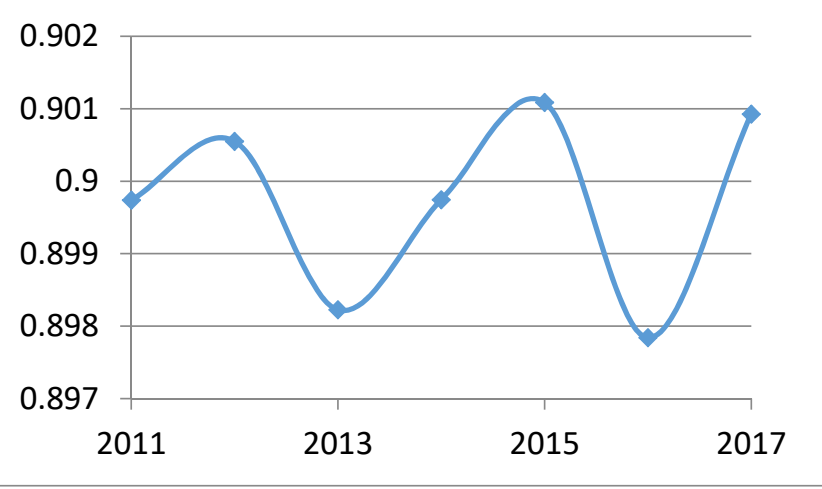

Figure 3. Distribution of actual values for bankruptcy probability on the basis of Monte-Carlo simulation in “Baysad'JSC, units 


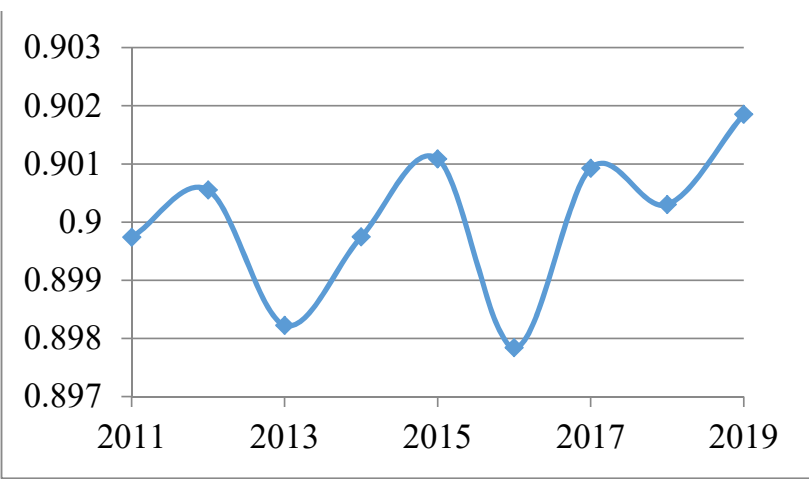

Figure 4. Distribution of projected values for bankruptcy probability based on Monte-Carlo simulation at "Baysad" JSC, units

The software contains estimate of unexpected losses, i.e. VaR. Most probable distribution and frequency of occurrence over defined period $(90 \%$ percentile of losses distribution is average value over 1 year (optimal period for financial managers accurately control financial risks in Russian corporations)).

Considering probability of $90 \%$, in 2017 unexpected losses should not exceed 54,488,800 rubles in "Arnest" JSC, 286,135 thousand rubles in "Soyuzpechat" JSC, 1,678,598 thousand rubles in "Baysad" JSC, and 252655 thousand rubles in "Georgievsky Fittings Plant" LLC. Considering probability of $10 \%$, in 2019 unexpected losses may exceed 5886121 thousand rubles in "Arnest" JSC, 240174 thousand rubles in "Soyuzpechat" JSC, 1808635 thousand rubles in "Baysad" JSC, and 315688 thousand rubles in "Georgiyevsky Fittings Plant" LLC.

At the same time, one of the possible methods to protect organizations from unexpected losses is stress testing, which evaluates their status in conditions of uncertainty. Since each corporation is individual in its risk profile and lack of generally accepted standards for stress testing, each corporation should develop stress tests from time to time. Surely corporations' strategies stress testing should allow corporations to face even uncertain future and keep leading positions. Financial risk decisions on stress testing are based on professional judgment and rationality, as well as best previous experience. Stress tests should be regularly updated, refined and modified under supervision and with the direct participation of top management to reflect changes in external environment factors and behaviour of stakeholders. Each stress scenario should be supported with risk prevention measures plan that should include list of procedures to undertake in case of risk situations in corporations. The results of stress testing should be considered for developing / improving Financial Risk Management Policy of organizations. Stress testing involves taking into account factors causing high financial risk in corporations at uncertainty environment.

Monte Carlo is a universal method that allows:

- develop internal modelling;

- take into account random processes and risk parameters values, ultimately formalizing description of uncertainty;

- create and evaluate a list of possible stress scenarios, and select alternative financial risk solution;

- comprehensively take into account possible uncertainties and comparative most probable financial risk decisions for each of the stress scenarios;

- identify financial back up for unexpected losses with reference to stress data in the context of economic cycle phases, and implementing principles of dynamic proviso;

- obtain baseline data for assessing and projecting risk indicators values attracting modern technologies for their control;

- determine financial risk point-wise values by economic cycle phases, that should reflect optimal interval limit with reference to applied method, and exclude pro-cyclicality;

- assess stakeholders' behaviour in financial markets.

Evaluation of strategic financial potential of corporations based on the Monte Carlo method draws special attention [7].

To exclude inefficient financial risk decision making, there should be limits allocated for support of certain financial indicators for operations carried out in areas of catastrophic and critical risks (share of highly liquid assets to form "liquid cushion", share of external / borrowed capital, maximum credit volume provided to one buyer, future liability limits, solvency requirements, etc.). At the same time, those should not limit organizations' possibilities for dynamic financial opportunities.

\section{Results}

\subsection{In theoretical block of the research:}

- Terminological and methodical uncertainty was defined for interpretation of expected and unexpected losses in Russian financial management practices, improved conception defines sources of uncertainty as unexpected losses and behaviour of those stakeholders, which influence corporative meso- environment;

- Terminological contradictions were identified for characteristics implemented by Russian legislator for the terms of reserve funds and capital, which boils down to the following: the term "fund" by 
its semantic purpose should represent earmarked allocations, whereas the capital represents multipurpose allocations. Still, the Russian legislator not recognizing principle difference between the terms of "reserve fund" and "reserve capital" denotes intended purpose for both as to cover unexpected losses and admits that the case of unexpectedness is an approximation of uncertainty that theoretically excludes possibility of negative events, and that is unacceptable in case of uncertainty;

- inconsistency of classical conception for expected and unexpected losses is proved; the conception lacks clear classification of losses by their function in theory and practice of financial management, own capital is directly intended to cover unexpected losses, which prevents its efficient influence at organization's performance;

- formal nature of reserve fund creation in jointstock companies was uncovered, this fact limits its strictly targeted purpose, and reveals low level of financial risk culture in Russian joint-stock companies;

- comparison of classic and improved conceptions of expected and unexpected losses is carried out - Table 3.;

- concept for risk-capital is formulated as allocation of own capital aimed to compensate for losses expected from financial risks, where top-management may put it at risk, lose in a certain period of time, provided business stays operational;

- it was established that the creation of risk-capital allows integration of expected losses defined to a certain level of significance and of various types of financial risks, and ensures significant risks forecast that positively affects risk profile management in corporations;

- assessment of formal quasi risk-capital, i.e. reserve fund in JSCs confirms that their riskcapital does not protect against expected losses, but only formally meets the requirements of the National legislator;

- advantages of stakeholders' participation in the process of financial risk decisions making on

- expected and unexpected losses estimates were determined; for their relations with organizations are based on resource exchange.
Table 3. Comparison of classic and improved conceptions of expected and unexpected losses in corporations

\begin{tabular}{|c|c|c|}
\hline Criteria & $\begin{array}{c}\text { Classic } \\
\text { (in practice) }\end{array}$ & Improved \\
\hline $\begin{array}{l}\text { Sources of } \\
\text { compensation } \\
\text { for expected } \\
\text { losses }\end{array}$ & $\begin{array}{l}\text { Supplement } \\
\text { to the } \\
\text { market value } \\
\text { of services, } \\
\text { current } \\
\text { income and } \\
\text { back up } \\
\text { allocations }\end{array}$ & $\begin{array}{l}\text { Risk capital, with } \\
\text { records of loss causes, } \\
\text { it is admitted that } \\
\text { financial risk- } \\
\text { decisions of managers } \\
\text { imply expected losses; } \\
\text { source of risk is } \\
\text { unexpected losses. }\end{array}$ \\
\hline $\begin{array}{c}\text { Sources of } \\
\text { compensation } \\
\text { for } \\
\text { unexpected } \\
\text { losses } \\
\end{array}$ & $\begin{array}{l}\text { Own capital } \\
\text { capturing loss } \\
\text { facts }\end{array}$ & Uncertainty \\
\hline $\begin{array}{l}\text { Properties of } \\
\text { loss } \\
\text { compensation } \\
\text { sources }\end{array}$ & $\begin{array}{l}\text { Static } \\
\text { character }\end{array}$ & Dynamic character \\
\hline $\begin{array}{l}\text { Sources of } \\
\text { uncertainty }\end{array}$ & $\begin{array}{l}\text { Is not clearly } \\
\text { identified }\end{array}$ & $\begin{array}{l}\text { Unexpected losses and } \\
\text { behaviour of those } \\
\text { stakeholders, which } \\
\text { influence corporative } \\
\text { meso- environment }\end{array}$ \\
\hline $\begin{array}{l}\text { Back up } \\
\text { protection } \\
\text { levels } \\
\end{array}$ & Regulatory & $\begin{array}{l}\text { Individual and } \\
\text { sufficient }\end{array}$ \\
\hline $\begin{array}{l}\text { Buffers } \\
\text { treatment }\end{array}$ & $\begin{array}{l}\text { Supplement } \\
\quad \text { to the } \\
\text { market value } \\
\text { of services }\end{array}$ & $\begin{array}{l}\text { Supplement to the } \\
\text { market value of } \\
\text { services, stock buffer } \\
\text { of highly liquid assets }\end{array}$ \\
\hline $\begin{array}{l}\text { Nature of } \\
\text { back up } \\
\text { allocations }\end{array}$ & $\begin{array}{l}\text { Formal and } \\
\text { insufficient }\end{array}$ & $\begin{array}{l}\text { Dynamic, based on } \\
\text { inclusion of business } \\
\text { cycle phases }\end{array}$ \\
\hline $\begin{array}{l}\text { Participation } \\
\text { in risk profile } \\
\text { creation }\end{array}$ & Formal & $\begin{array}{l}\text { Risk capital is a direct } \\
\text { part for its creation }\end{array}$ \\
\hline $\begin{array}{l}\text { Stakeholders' } \\
\text { involvement }\end{array}$ & $\begin{array}{l}\text { No } \\
\text { involvement }\end{array}$ & $\begin{array}{l}\text { Involvement in } \\
\text { financial risk decision } \\
\text { making and in loss } \\
\text { forecast process }\end{array}$ \\
\hline $\begin{array}{l}\text { Level of } \\
\text { financial risk } \\
\text { culture }\end{array}$ & $\begin{array}{l}\text { Low and of } \\
\text { formal } \\
\text { character }\end{array}$ & Expected to be high \\
\hline
\end{tabular}

Source: compiled by authors Manuylenko and Ryzin

\subsection{In Practical Block of the Research}

Bankruptcy risk was determined with attraction of point and rating methods, estimation of HennenHenvek index for the least sustainable forms of corporative business in "Georgievsky Fittings Plant" LLC and "Baysad" JSC. 
Hennen-Henvek index for bankruptcy risk is determined as follows, Table 4.:

\author{
Hennen-Henvek \\ index $=$ \\ $\underline{\mathrm{CR}+\mathrm{OC} / \mathrm{TC}}$ \\ $\delta \mathrm{CR}$ \\ 3) \\ where CR- Total capital return; \\ OC/ TC- Own Capital / Total Capital;
}

$\delta_{\mathrm{CR}}-$ Standard deviation of total capital return

Table 4. Determination of bankruptcy risk by the HennenHenvek index in corporations in 2017, in units

\begin{tabular}{|l|c|c|}
\hline Corporations & $\begin{array}{c}\text { Share of own } \\
\text { capital in total } \\
\text { capital }\end{array}$ & $\begin{array}{c}\text { Total capital } \\
\text { return }\end{array}$ \\
\hline 1 & 2 & 3 \\
\hline "Arnest" JSC & 0,511 & 0,066 \\
\hline "Baysad" JSC & 0,246 & 0,004 \\
\hline $\begin{array}{l}\text { "Georgievsky } \\
\text { Fittings Plant" }\end{array}$ & 0,013 & 0,008 \\
\hline rLC & $\begin{array}{c}\text { Standard } \\
\text { deviation of } \\
\text { total capital } \\
\text { return }\end{array}$ & $\begin{array}{c}\text { Hennen-Henvek } \\
\text { index for } \\
\text { bankruptcy risk } \\
\text { group 2 + group } \\
3) / \text { group 4 }\end{array}$ \\
\hline $\begin{array}{l}\text { "Arnest" JSC } \\
\text { Fittings Plant" }\end{array}$ & 0,024 & 5 \\
\hline LLC & 0,014 & 24,042 \\
\hline
\end{tabular}

Source: calculations provided by the authors V. V. Manuilenko, D. A. Ryzin on the data [3].
It is believed that the lower is the index, the higher is the bankruptcy risk. According to the value of the Hennen-Henvek index, high bankruptcy risk is noted in "Georgievsky Fittings Plant" LLC, further "Baysad" JSC is listed with much lower bankruptcy risk, and the last on the list is "Soyuzpechat" JSC with the lowest probability of capital loss.

In modern environment, scores or rating scores represent better alternative to scattered estimates; those are aimed at identification and assessment of aggregated financial risk in corporations, in the end providing evaluation of financial management efficiency. It should be noted that the scores or rating scores are attractive to stakeholders, especially at the point of potential partner justification and planning on agreement with significant value.

Model for integrated financial risk scoring in organizations implies regulatory range compliance for 8 relative indicators to classes / intervals - Table 5.; analyst assigns points according to those values. Generally, corporations may be assigned to a corresponding risk class, but classification 3 and above points at the signs and risks of bankruptcy. Financial leverage indicators in the models are comparative with the level of capitalization, Dontsova and Nikifirova [5] both agree with the stipulation.

Table 5. Implementation of a model for comprehensive scoring of financial risk in "Arnest” JSC

\begin{tabular}{|l|c|c|c|c|c|c|c|}
\hline \multirow{2}{*}{ Indicators } & \multicolumn{9}{c|}{ YY } \\
\cline { 2 - 9 } & 2011 & 2012 & 2013 & 2014 & 2015 & 2016 & 2017 \\
\hline Absolute liquidity, units & 0,982 & 0,723 & 0,809 & 1,117 & 0,651 & 0,911 & 0,222 \\
\hline SCORES & 14 & 14 & 14 & 14 & 13 & 14 & 3 \\
\hline "Critical" estimates (intermediate liquidity), units & 1,2 & 0,996 & 1,105 & 1,639 & 1,146 & 1,617 & 1,75 \\
\hline SCORES & 11 & 10,8 & 11 & 11 & 11 & 11 & 11 \\
\hline Current liquidity, units & 2,618 & 1,996 & 1,909 & 3,068 & 2,0 & 2,791 & 2,75 \\
\hline SCORES & 20 & 19 & 19 & 20 & 20 & 20 & 20 \\
\hline Share of current assets in overall assets, units & 0,549 & 0,585 & 0,574 & 0,573 & 0,553 & 0,582 & 0,471 \\
\hline SCORES & 10 & 10 & 10 & 10 & 10 & 10 & 7 \\
\hline Provision of working capital, units & 0,172 & 0,102 & 0,118 & 0,084 & $-0,022$ & 0,05 & $-0,039$ \\
\hline SCORES & 0,3 & 0,25 & 0,27 & 0,2 & 0,2 & 0,2 & 0,2 \\
\hline Financial leverage (capitalization), units & 0,834 & 1,108 & 1,027 & 1,102 & 1,30 & 1,236 & 0,958 \\
\hline SCORES & 17,6 & 13 & 11 & 12 & 8 & 7 & 17,5 \\
\hline Financial independence, units & 0,545 & 0,474 & 0,493 & 0,476 & 0,435 & 0,447 & 0,511 \\
\hline SCORES & 9,0 & 7 & 8 & 7,5 & 5 & 6 & 9 \\
\hline Sustainability, units & 0,671 & 0,561 & 0,573 & 0,733 & 0,627 & 0,736 & 0,829 \\
\hline SCORES & 3 & 2 & 2 & 4 & 3 & 4 & 5 \\
\hline$\sum$ SCORES & 84,9 & 76,05 & 75,27 & 78,7 & 70,2 & 72,2 & 72,7 \\
\hline CLASS OF CORPORATION & \multicolumn{7}{|c|}{2} \\
\hline AREAS OF RISK & \multicolumn{7}{|c|}{ tolerable risk } \\
\hline
\end{tabular}

Source: calculations provided by the authors V. V. Manuilenko, D. A. Ryzin on the data [3]. 
Among the researched corporations, "Arnest" JSC and "Soyuzpechat" JSC do not show bankruptcy symptoms. During the retrospective period, "Arnest" JSC is floating in the area of tolerable risk. "Soyuzpechat" JSC stays within acceptable risk level in 2011, 2016, and in 2012 - 2015, 2017 - stays in risk-free zone. The financial risk of "Baysad" JSC in 2011-2012 is devastating, in 2013, 2015-2017 critical, in 2014 - high. "Georgievsky Fittings Plant" LLC in 2011, 2015 - 2017 relates to class 4, and in 2012 - 2014 to class 5.

Stakeholders - creditors, lenders and investors have reasons to doubt due fulfilment of obligations of "Baysad"JSC and "Georgievsky Fittings Plant" LLC. Application of integrated financial risk assessment model identifies sufficient list of signs for financial stability risk of corporation.

Stakeholders appreciate rating the models for assessing bankruptcy risks. Distinctive feature of most of them is mathematical approach and professional extraction of a number of components that form the consequential rating, which objectively reflects the bankruptcy risk for organization. In the Russian environment of instability, 5-factor rating model for bankruptcy risk identification generates interest. The model by A. Postyushkov, implemented in countries with transition economies referers to 6month forecasting scope, and can be used for different type of business and different size of business - Table 6. Bankruptcy risk is revealed via measurement of liquidity indicators, business activity, profitability, commercial margin and the rate of capital turnover, where all of those are the key factors affecting profitability of overall capital that includes own capital.

According to rating indicator value of A. V. Postushkov's model, throughout the entire retrospective period, only "Soyuzpechat" JSC financial situation is considered satisfactory, which indicates that bankruptcy risk in corporations in varying degrees is present in "Georgievsky Fittings Plant" LLC and "Baysad" JSC. Stakeholders, following their own goals, can independently apply required composition of indicators, regulatory restrictions taking into account national regional environment, specifics, type of business and other parameters.
Table 6. Bankruptcy risk assessment results for researched corporations by means of 5 factor rating model, in units

\begin{tabular}{|c|c|c|}
\hline YY & "Arnest" JSC & "Soyuzpechat" JSC \\
\hline 2011 & 1,033 & 2,703 \\
\hline 2012 & 0,978 & 2,880 \\
\hline 2013 & 0,820 & 2,798 \\
\hline 2014 & 0,804 & 3,126 \\
\hline 2015 & 0,538 & 2,704 \\
\hline 2016 & 0,737 & 1,8 \\
\hline 2017 & 0,576 & 2,130 \\
\hline & "Baysad" JSC & "Georgievsky Fittings \\
& $-1,640$ & 1,092 \\
\hline 2011 & $-1,132$ & $-6,117$ \\
\hline 2012 & $-0,914$ & $-4,109$ \\
\hline 2013 & $-1,674$ & $-3,620$ \\
\hline 2014 & $-0,156$ & 1,927 \\
\hline 2015 & 0,278 & 60,988 \\
\hline 2016 & 0,233 & $-0,567$ \\
\hline 2017 & & \\
\hline & & \\
\hline
\end{tabular}

\subsection{In methodological block of the research:}

- model for unexpected losses VaR estimation was adapted and implemented, which integrates costwise probabilistic and time-wise measurement of financial risk in corporations; growth tendency for unexpected losses mainly in regional corporations was identified (with exception of "Soyuzpechat" JSC);

- requirements were justified for synergy of methods, techniques, tools for measuring unexpected losses, including VAR, internal modelling, stress testing based on Monte-Carlo simulation, as well as setting limits on the support of certain financial indicators.

\section{Conclusion}

So, creation and implementation of alternative concept for expected and unexpected losses in corporations resulted in adaption and implementation of method for determining unexpected $\mathrm{VaR}$ supported with author software "Software for determining expected and unexpected losses in commercial corporate non-credit organizations". The application of the software ensures estimation support for financial risk decisions and increases the objectivity of decision making of both operational and strategic character. Successful implementation of alternative conception for unexpected and expected losses in corporations allows to: 
- identify expected and unexpected losses of joint financial and intellectual capitals functioning; separate study of intellectual capital in corporations was conducted by Galazova et al. [7];

- further develop methods and tools to identify unexpected and expected losses from bank risks [15], [16];

- further develop methods and tools to identify unexpected and expected losses from tax risks [9];

- develop methods, means and tools for uncertainty evaluation [11].

Authors believe that developed model for estimation of unexpected losses can be upgraded by changing forecast period. Taking into account the specifics of business advancement, each corporation can develop its own model for determining unexpected and expected losses.

Therefore, the study proved the need to replace the existing formal approach to determination of expected and unexpected losses with alternative conception, which provides coverage for expected losses with risk capital according to business cycle phases, as for unexpected losses it determines source of uncertainty using adapted VaR model, stress tests and limits. Subsequently, depending on the goals and objectives set by top-management of corporations, the VaR model can be modified.

Created alternative concept for expected and unexpected losses in commercial non-credit corporations has no analogues in the world, it develops the VaR concept, generally known in foreign financial practice and is used exclusively by financial institutions. In addition, the study gives preference to the foreign practice of assessing bankruptcy risk by the Hannan-Hanvek Index. In view of the foregoing, it is reasonable to indicate the parameters that set boundaries to the results of the study: the forecasting period independently determined by each corporation. In general, it is fair to admit that the alternative concept of expected and unexpected losses develops a new area in the system of strategic financial risk management in corporations, since it is aimed at covering expected losses with risk capital that assumes the losses caused during phases of the economic cycle. Unexpected losses, as a source of uncertainty, are regulated on the basis of the adapted VaR method, stress tests, and limits as per dynamic reservation principles.

\section{References}

[1]. Beger, A., Krushvits, Kr., Podobnik, G. and Rast, M. (2003). Capital management issues and approaches in German banks. Business and Banks, 658, 5-7 [in Russian].

[2]. Brighem, Yu. and Gapensky, L. (2017). Financial Management. Moscow, Russia: Books on Demand [in Russian].
[3]. Accounting reports of "Arnest" JSC, "Soyuzpechat" JSC, "Baysad" JSC, "Georgievsky Fittings Plant" LLC (2019). Company accounting reports base of the Federal Statistics Service of Russia

Retrieved from: http://www.gks.ru/accounting_report . [accessed: 14 February 2020].

[4]. Domashenko, D.V. and Finogenova, Yu.Yu. (2015). Risk management in uncertain financial environment. Moscow, Russia: Infra-M [in Russian].

[5]. Dontsova, L. V., \& Nikifirova, N. A. (2018). Financial statement analysis: practice. Moscow, Russia: Delo \& Service [in Russian].

[6]. Fabozzi, F.J. (2007). Bond Markets, Analysis and Strategies: 2nd edition. Moscow, Russia: Alpina Business Books [in Russian].

[7]. Galazova, S. S., Manuylenko, V. V., Morgoev, B. T., Lipchiu, N. V., \& Biganova, M. A. (2017). Formation of Stakeholders' Client Capital of Trade Institutions. European Research Studies, 20(4B), 398411.

[8]. Manujlenko, V. V., \& Ryzin, D. A. (2018). Ožidaemye $\mathrm{i}$ neožidaemye poteri $\mathrm{v}$ processe upravlenija finansovymi riskami korporacij: al'ternativnyj vzgljad. Problemy èkonomiki i juridičeskoj praktiki, (3). 55-59. [in Russian].

[9]. Miller, A. E., Gorlovskaya, I. G., \& Miller, A. A. (2016). Development of a mechanism of increasing tax revenues to regional budgets through the development of the securities market. Journal of Internet Banking and Commerce, 21(S4), 018-018.

[10]. Ploshkin, V.V. (2014). Evaluation and risk management in business. Stariy Oskol, Russia: TNT [in Russian].

[11]. Rutkauskas, A.V. and Stasytytè, V. (2010). Effectiveness, reliability and subject risk-shaping drivers for the set of possibilities and utility function when investment decision is made under uncertainty. The 6th International Conference "Business and Management 2010": May 13-14, 2010, Vilnius, Lithuania: Technika, 176-183.

[12]. Sinkey, J. (2016). Commercial Bank Financial Management in the Financial-Services, Moscow, Russia: Alpina Business Books [in Russian].

[13]. Skovorodkina, L. V. (2011). Finansovyj menedžment. Čast' 2.: učebno-metodičeskoe posobie.

[14]. Smith, A. (2016). An Inquiry into the Nature and Causes of the Wealth of Nations. Moscow, Russia: Exmo [in Russian].

[15]. Voronova, N. Y. S., \& Miroshnichenko, O. S. (2018). People's Incomes as a Potential for Development of Bank Lending: Comparative Analysis of Russian Regions. Economic and Social Changes-Facts Trends Forecast, 11(4), 144-159.

[16]. Voronova, N. Y. S., Miroshnichenko, O. G. S., \& Tarasova, A. N. (2016). Determinants of the Russian Banking Sector Development as the Drivers of Economic Growth. Economic and Social Changes: Facts, Trends, Forecast, (4), 165-183. 